The Bone Motif and Lambs in the Turkish Folktale "The Reed Door"

Author(s): Şükriye Ruhi

Source: Asian Folklore Studies, 2000, Vol. 59, No. 1 (2000), pp. 59-77

Published by: Nanzan University

Stable URL: https://www.jstor.org/stable/1179027

JSTOR is a not-for-profit service that helps scholars, researchers, and students discover, use, and build upon a wide range of content in a trusted digital archive. We use information technology and tools to increase productivity and facilitate new forms of scholarship. For more information about JSTOR, please contact support@jstor.org.

Your use of the JSTOR archive indicates your acceptance of the Terms \& Conditions of Use, available at https://about.jstor.org/terms 


\title{
The Bone Motif and Lambs in the Turkish Folktale "The Reed Door"
}

\begin{abstract}
The Aarne-Thompson Tale Type 123, "The Wolf and the Kids," is present in Turkish folklore in a number of variants. This study examines an oral version of the tale in which the plot diverges from other variants. In the tale, the wolf threatens to eat the parents, while the offspring function as protectors of the household. Both parents and offspring are eaten by the wolf. This study analyzes the divergence and the significance of the lamb, the lamb's bones, and the door in the tale through a semantic comparison of these elements with their communicative value in Turkish folklore material and discourse. The underlying semantic coherence of these elements reveals that they represent children as protectors of the family. Based on the premise that narratives are forms of communication, the study argues that the main communicative value of the tale is its function as a metaphor for family patterns in Turkish culture, where children are perceived as being essential to the well-being of the family.
\end{abstract}

Keywords: bone motif-comparative folktale discourse-lamb-Tale Type 123 in Turkish folktales 
$\mathrm{S}$ IMILAR MOTIFS AND PLOTS have formed the criteria for the classification of world folktale literature. While the similarities found in tales throughout world literature are intrinsically interesting, the differences within the same typological category are also interesting because they can reflect differences in the significance of the tale in the culture in which it emerges. Discussing various approaches to the comparative method in folklore research, DUNDES focuses on the need to study the particular version of a folktale common to one cultural context. He points out that such studies may inform us on "how folklore is modified to fit local ideological or world view tendencies" $(1989,73)$. This suggests that variants of a folktale type in a geographical or national region may point to the cultural values existing within the worldview of a particular community.

This study examines a Turkish folktale of the Aarne-Thompson Type 123 that contains a bone motif, and attempts to analyze its significance within the context of its tale typology. It further illustrates the motif by relating it to certain cultural elements in ancient narratives, folk beliefs, taboos, formulaic expressions, and conversational conventions in contemporary Turkish discourse. The analysis is based on the premise that the communicative value of an element in folklore emerges through the semantic coherence that the element exhibits in comparative studies of the element in other discourse genres, whether these be nursery rhymes, epics, or belief systems (KARABAŞ 1977, 176; DUNDES 1989, 89-90). This premise is consistent with the claims in narratology that narratives essentially involve a communicative intent and are not narrated solely for the purpose of telling a good story (RIGNEY 1992, LABOV 1972, GÜLICH and QUASTHOFF 1985). Hence, folktales, as a form of narrative, are also forms of communication.

The plot of AT 123 is summarized as follows in ASHLIMAN $(1987,26)$ :

[W] hen mother goat was away, the wolf came to her house and ate her kids. The mother found the villain asleep in the meadow and cut open his belly. Out sprang the kids, for the wolf had swallowed them whole. 
The mother filled his belly with stones and sewed him shut. When he awoke he went to a well to drink. The stones made him fall in, and he drowned.

The folktale to be examined in this study, "The Reed Door,"exhibits interesting divergences from both the plot above and those of published versions of AT 123 in Turkish folklore. The differences between "The Reed Door" and published variants of AT 123 in Turkish folklore are discussed in the section below.

\section{The TAle: "THE ReEd DooR"}

Synopsis and text

Three versions of "The Reed Door" have been recorded. In the version for which it has been possible to obtain a full oral narration (henceforth RD1), a husband and wife of humble means live together with their lamb. One day a wolf comes to their door and threatens to eat the husband and wife. In response, the lamb, with a bold tone rendered through the change in the voice of the narrator, threatens to injure the wolf and eat it. Upon hearing this voice, the wolf shies away. The same event takes place a number of times until one day the couple decides to eat the lamb. They butcher it and throw the bones into the garbage can. On the following day, the wolf comes again but is held off by the speaking bones of the lamb in the garbage can. Then, the garbage collector takes away the bones along with the garbage; the wolf eventually eats the couple when it breaks down the door upon not hearing the threatening voice of the lamb.'

A translation of $\mathrm{RD} 1$ is given below, with its original in the Appendix to this article. Each numbered line in the translation refers to a single independent clause in the original, except for the introductory run that is given in line (a). The roman numerals indicate the starting points of the setting, complication, turning point, and resolution, respectively in the story. The runs that express the words uttered by the wolf in front of the door (lines $c$ ) and the holding off of the wolf by the lamb (lines $\mathrm{d}$ ) are written in italics. ${ }^{2}$

(a) In times of old, the sieve in the hay, when camels were town criers, when fleas were barbers, when I was gently rocking my father's cradle

I.

(b) in some land, in a tiny little house, lived a husband and wife, and their tiny little lamb. 
II.

(c) While this family was living in peace, one day a wolf came in front of the door

(cc) and this is what it said:

(ccc) "Reed door, I will break you;

(cccc) Husband and wife, I will eat you," it said.

(d) The lamb inside said:

(dd) "I'll hit with my horn,

(ddd) prod you with my tail.

(dddd) Don't come in,

(ddddd) I'll eat you," it said,

(e) and the wolf got frightened,

(ee) and ran away.

(c) The following day the same event happened again.

(cc) The wolf comes:

(ccc) "Reed door, I will break you;

(cccc) Husband and wife, I will eat you," it says.

(d) From inside our lamb again:

(dd) "I'll hit with my horn,

(ddd) prod you with my tail.

(dddd) Don't come in,

(ddddd) I'll eat you," it says.

(e) The wolf, frightened, runs away again.

III.

(f) The following day, the husband and wife decide:

(ff) "Let's butcher this lamb and

(fff) eat its meat," they say.

(ffff) And they butcher it.

(fffff) The poor little lamb-they eat its meat.

(ffffff) They put its bones into the garbage can.

(c) The following day the wolf comes again:

(cc) "Reed door, I will break you;

(ccc) Husband and wife, I will eat you," it says.

(d) This time the bones of the lamb in the garbage can:

(dd) "I'll hit with my horn,

(ddd) prod you with my tail.

(dddd) Don't come in,

(ddddd) I'll eat you," it says.

(e) The wolf, frightened, runs away again.

(g) The following day the garbage collector comes. 
(gg) He takes the garbage away.

(c) The wolf comes again:

(cc) "Reed door, I will break you;

(ccc) Husband and wife, I will eat you," it says,

(h) and it stops, it waits and waits.

(hh) No sound comes from inside.

IV.

(hhh) It breaks the door,

(hhhh) gets in,

(hhhh) and eats up the husband and wife.

The two other versions of "The Reed Door" have been collected in a synoptic form. In one of these (henceforth, $\mathrm{RD} 2$ ), two lambs prevent the wolf from entering the house and eating the parent sheep. One day the parent sheep leave the house in search of food and the wolf eats the lambs. When the parents return, they find the bones of the lambs and throw these away. Similar to the plot in RD1 above, the parents are protected from the wolf as long as the bones remain in the garbage can, but after these are collected by a garbage collector, the wolf eats the parent sheep. It is especially this version of the tale that has led to its being classified as belonging to AT 123. It resembles the tale type more closely in that the wolf manages to eat the lambs when the sheep leave the house. In the other version (henceforth $\mathrm{RD} 3$ ), human characters replace the sheep and lamb figures, but the plot remains identical to $\mathrm{RD} 2$ in that the wolf eats the children when the parents are away from the house to get food. ${ }^{3}$ These two versions, too, include the characteristic runs uttered by the lambs/children and the wolf.

As can be seen in THOMPSON's Motif-Index of Folk Literature (1955), speaking animals and the magical powers of the bones of both humans and animals in folktales are motifs that frequently appear in folktale literature. While the former motif of speaking animals is also common in collections of Turkish folktales (cf. for example, BoraTAV 1992a, 1992b, KunOS 1991, HelimoĞLU YAVUZ 1997, WALKER 1988), bone motifs in Turkish folktales are rare. Thus, folktales that do include such a motif could reveal information on its symbolic meaning and how the tale itself fits into the folklore of a particular community.

"The Reed Door" is one such folktale in Turkish folklore. Through the analysis of the tale's plot and the protective function of the bones in the tale, it will be argued that the tale reflects the social value attached to the traditional family structure in Turkish society. The belief in the power of bones in Turkish communities is noted in studies on symbolism and folklore 
(Chevalier and GHEerbrant 1994, EyuboĞLu 1998). The study relates the belief to the performative role of the lambs/children in the tale regarding the family structure in Turkish society. It will be seen that the bone motif in the tale acquires special significance when compared to other variants of AT 123 in Turkish folklore.

\section{"The Reed Door" and Variants of AT 123 in Turkish Folktales}

AT 123 is present in several published collections of Turkish folktales (BorataV 1992a, HelimoĞlu YaVuZ 1997, Silay 1988, Walker 1988). In BORATAV (1992a, 33-35), the lambs are eaten up by the wolf when it tricks them into believing that it is their mother. The sheep finds the lambs' bones in the house and invites the wolf for dinner. When the wolf arrives, the sheep makes the wolf sit on a cushion that the sheep had placed over the mouth of a small pit. The wolf burns in this pit. The sheep gives birth to two more lambs and lives happily thereafter. The version in HeLimoĞLU YAVUZ's (1997, 388-90) collection includes the motif of the wolf's belly being ripped and the kids being saved, while in SILAY (1988, 61-62) the lambs protect themselves by making the wolf go in search of the key to the door under a nearby tree. There, the wolf sights a sheep dog and changes his mind about eating the lambs. In this version only is the wolf unable to deceive the lambs. Finally, in WALKER's $(1988,4-7)$ variant a bear replaces the wolf. In this variant, the bear eats one of the kids. The nanny goat invites the bear for dinner, promising to cook the other kid for him. When the bear arrives, the nanny goat tricks him into falling into a cellar and rips his stomach to save the kid that had previously been eaten up by the bear.

In all these variants, the wolf/bear attempts to get into the house by presenting itself to the lambs/kids as the sheep/nanny goat. In other words, the threat is to the lambs/kids. Furthermore, except for the variant in SILAY (1988), where the lambs are able to protect themselves, the sheep/nanny goat are depicted as being more or less capable of protecting their progeny even though this can only be accomplished through giving birth to new lambs in BORATAV's (1992a) collection. Thus, all these variants have a happy ending and resemble the plot of AT 123 as summarized by AsHLIMAN $(1987,26)$. Reference to the lambs' bones is present only in Boratav's collection, probably due to the fact that the threatened lambs are irrevocably lost only in this variant

"The Reed Door" diverges from the tale type found in the collections cited above in several respects. First, the wolf threatens to eat the parent sheep/humans in all three versions. Second, the lambs/children act as protectors of the household and are not saved at the end of the story. Third, "The Reed Door" includes a bone motif, where the bones of the lambs/children 
function to protect the sheep/human figures. Furthermore, in all three versions the wolf also eats the human adult figures or the parent sheep after the death of the lambs/children.

One published variant of AT 123 in Turkish folktales is rather different from those mentioned so far in that it has an ending similar to that of "The Reed Door." The title of the tale is "The Lamb with Henna," and the figure eaten by the wolf is a girl whom the mother in the tale calls "my lamb with henna" (GÜRGÖZE 1997, 127). In the story, the wolf manages to enter the house by imitating the voice of the mother, and eats up the girl. "My lamb" and "my little lamb" are traditional terms of endearment frequently used by parents for their children, while "my lamb with henna" is used specifically for daughters. Such expressions are also present in Turkish discourse when referring to children in the care of other adults such as teachers and caretakers. In folkloric material such as the mani, "lamb" refers to youth of either sex (KARABAS 1996, 67). ${ }^{4}$ Thus, it appears that neither the replacement of the lamb figure by children nor the death of offspring are features characteristic of just "The Reed Door" in AT 123 in Turkish. From this comparison, it may be concluded that lambs/kids and children are interchangeable figures in AT 123 in Turkish folktales. In this sense, the lamb figure may be taken to symbolize children both in "The Reed Door" and in other variants of AT 123 in Turkish folktales.

Comparing the role of the lambs/children in the "The Reed Door" with that in published variants of AT 123, the closest resemblance appears to be to the variant in SILAY (1988) in that the progeny exhibits a higher degree of agency regarding protection. Even though the lambs/children in "The Reed Door" die in the story, they are presented as protectors of the household, and in SILAY $(1998,62)$ the lambs can fend for themselves. In this sense, it seems plausible to argue that plot development in at least some of the variants of AT 123 in Turkish folktales foregrounds the role of offspring in the survival of the species. ${ }^{5}$

It should be pointed out here, though, that RD1 is significantly different from all the variants discussed above since the husband and wife butcher the lamb in the tale. In contrast, in RD2 and RD3 the lambs/children are eaten up by the wolf. As such, it might be argued that $\mathrm{RD} 1$ is an aberrant case of AT 123 in Turkish folktales since it includes a motif where adult figures kill offspring. However, as argued by DUNDEs $(1989,74)$, individual narrators can reflect their own worldviews and communicative intentions when narrating stories such that the same tale type may be rendered with varying degrees of difference. How this difference relates to communicative intentions is taken up for discussion in the ensuing sections of the study.

The titles of published variants of AT 123 are also different from "The 
Reed Door." In BorataV (1992a) and SiLAY (1988) these are "The Lambs, Ayşe and Fatma," where Ayşe and Fatma are names of females in Turkish. The titles derive from the first line of the run that the sheep utters to the lambs on returning from the fields. In HeLimoĞLU YAVUZ (1997), it is "The Goat and the Wolf," while WALKER's (1988) variant has "Who's There? And What Do You Want?" which are the words that the kids, Medik and Muduk, utter to the bear. These names are gender neutral and do not exist in Turkish. Their phonological form, however, connotes smallness. The relation between the gender of the lambs in "The Reed Door" and family structure is discussed below in the section on lamb symbolism in Turkish culture.

\section{Narrative Characteristics of "The Reed Door"}

On the linguistic level, the perspective of the narration in RD1 is that of the lamb. This is evident from a number of cues that guide the listeners to empathize with the lamb. These cues are the evaluative, descriptive expressions "tiny little lamb," "our lamb," and "the poor lamb" in the setting and the complication in the plot (see, lines $\mathrm{b}$ and $\mathrm{d}$ above). They also prepare the listeners for the ending of the story. It is interesting to note that such evaluative remarks do not exist in the variants of AT 123 in the published collections cited above.

The tale includes one of the characteristic runs of tale openings in Turkish folktales (cf. ZEYREK 1993); however, it does not have a closing run. This is because the end of the story contrasts with the plot structure of most folktales in Turkish, which have a "happy ending." In one way or another, most Turkish folktales that include a threat to the protagonists resolve the complication in the plot in a manner that satisfies the expectations of the listeners. In other words, the good are rewarded and the bad are punished.

\section{The Bone Motif in "The Reed Door" and Other Turkish Folktales}

Thompson's Motif-Index of Folk Literature includes several motifs of bones having magical powers. A number of these relate to bones having the power of revival. For example, in D437.1 bones are transformed to a person; in others, bones are involved in resuscitation (E29.1, E174, D1886.1, E29.2). In another motif, E366.3, a bone advises the hero in the tale. There is also the widespread folktale indexed as "The Singing Bone" (E632, AT 780), where bones reveal a crime. ${ }^{6}$

Within the context of these motifs, the speaking bones in "The Reed Door," are closest to the E366.3 motif (talking bone advises hero) insofar as they protect the parents (sheep or human) in the tale. A similar motif that combines protection with magical power is present in "The Tale of the Black Cow," a version of the Cinderella tale (KuNOS 1991, 164-67). In the tale, 
before being killed, the mother advises the daughter to keep her bones buried under a rose bush so that they may be a source of consolation for the girl. From these bones, a fairy emerges to provide her with clothes, money, and a carriage to go to a wedding feast. In another tale, "The Smile of the Fish," (HELIMOĞLU YAVUZ 1997, 293-97) a girl becomes pregnant as a result of a small piece of bone from a skull entering her mouth, a motif that is similar to T532.1.4.1 (conception from smelling the dust of bones). Thus, the bone motif is closely related to ideas regarding protection, rejuvenation, and conception in Turkish folktales.

The motifs cited above appear to be related to certain beliefs in some cultures regarding bones. CHEVALIER and GHEERBRANT (1994, 109-11) note several related beliefs in world cultures. Some consider bones "the essential and primordial element of the being," hence, the "least perishable part of the body" representing the "continuation of the species." The writers specifically mention the belief in some cultures that the bone contains "the most important soul," which leads to the bones of game being shown special reverence and care (Chevalier and GheERBrant 1994, 109). The Mongolo-Turkic peoples of the Altai are mentioned as one such culture. In his study on Turkic shamanistic beliefs and mythology, ÇORUHLU $(1999,69-70)$ notes that the shaman's clothes are decorated with bone motifs signifying the belief in the process of becoming a shaman through rejuvenation after a temporary loss of consciousness. In this process, the shaman's body is supposedly dismembered during a dream for the purpose of purifying the soul. After this, the shaman's soul re-enters the bones and the process of becoming a shaman is completed. EYUBOĞLU $(1998,161)$ also discusses a number of ancient folk beliefs and customs concerning bones in Anatolia. The bones of humans and some animals are hung on doors or windows for protection or are used in making ointment. In addition, he records a belief that the bones are the last to rot since the soul will be reborn by entering the bones. Thus, bones were regarded as revered objects and this belief has its remnants in contemporary Turkish society, where, for example, changing the place of a dead person's grave or damage to a grave are issues arousing strong emotional reactions among members of the family.

While the above-mentioned historical connections and folklore elements may shed light on the symbolic value of the bone motif in "The Reed Door," they alone are not useful for comprehending its specific semantic value. Of particular interest in the plot of the tale is why it should be that the lambs/children protect the household. It is necessary to look elsewhere-to ancient and extant narratives, contemporary discourse, and customs in Turkish communities - to discern its significance in the tale. 
Children, Lambs, AND Bones in Turkish Folklore and Culture

RiGNEY $(1992,267)$ argues that narratives "should be seen in the first instance as a communicative act carried out by a narrator who, for one reason or another, wishes to convey information about a certain set of events to someone else." According to this reasoning, the narrative is not just a representation of real or imagined events, but carries the function of making people see a set of events as something else from a particular perspective. In this sense, a narrative may function as a metaphor. Considering the frequent replacements of human and animal figures in folktales and the fact that the versions of "The Reed Door" include such replacements, it seems logical to analyze the plot in the tale not simply as an animal tale but as a metaphor concerning family structure and relations. The discussion of the bone motif and the role of the lambs/children in the tale will proceed on the premise that the tale is able of acting as a metaphor.

\section{Children in Narratives and Spoken Turkish Discourse}

To comprehend the performative role of the lambs/children in "The Reed Door" it is necessary to examine the role of children in Turkish culture. One of the earliest epic narratives in Turkish culture, Dede Korkut (lit., Grandfather/Wise man Korkut), constitutes a rich source on the family structure and customs of the Oghuz branch of Turkic tribes and provides clues on the origin of social and cultural values in contemporary Turkish communities.

The first narrative in the epic includes an episode that is telling with respect to the role of children in ancient and contemporary Turkish communities. In the initial setting of the narrative, Bayındir, the khan of the tribe, allots the leaders to tents of different colors at the annual feast he gives to leaders of clans under his rule. One of the leaders, Dirse Khan, around whom the narrative develops, has no child, and is, therefore, allotted to the black tent. This is an act of humiliation since having no child prevents one from acquiring status and respect in the community. That having progeny is the initial condition of gaining respect is underscored by the fact that, although Dirse Khan is humiliated, he accepts this as a social rule and does not foster ill feelings toward Bayındır Khan. This parallels the belief in the importance of children for the well-being and prosperity of the family in Turkish communities. Giving birth to children, especially to sons, increases status of daughters-in-law and strengthens emotional ties between them and parents of the husband in traditional Turkish families. Compliments expressed by in-laws include utterances like, "We like you very much. You have given us grandchildren."

Further examination of Dede Korkut is relevant for understanding the 
plot in "The Reed Door." Dirse Khan's wife gives birth to a son, but when he reaches the age of fifteen, the father attempts to kill him with an arrow because of slanderous remarks he hears about his son from his friends. Later, the son, Boğaç (lit., "like a bull"), saves his father, who had been kidnapped by the men in his clan. The narrative ends with the resolution of the conflict between the father and son, and the son's being conferred the title of khan after accomplishing an act of bravery (KARABAŞ 1996, 39-41 and REICHL 1992, 44-51). Thus, the motif of protection of parents by progeny is found both in this narrative and "The Reed Door." Another parallelism between the narrative and version $\mathrm{RD} 1$ of "The Reed Door" is observable in the motif of parental treachery. As noted earlier, published variants of AT 123 do not include such motifs.

In his discussion of the narrative structure of Dede Korkut, REICHL $(1992,51)$ emphasizes that childless couples are productive initial states in Turkic epic poetry and minstrel tales. The importance of bearing children is present in other ancient texts, too. In Kutadgu Bilig (lit., The Knowledge Leading to Happiness), a text of the eleventh century, the character, Öğdülmüs, representing wisdom and understanding, explicitly urges Ödgurmış to marry and have children. In the text, Öğdülmüş voices the values that are important to the society regarding such matters as family and ethics. That the advice is addressed to Ödgurmıs is important since he is a man who believes that mankind should engage himself in matters related to life after death. Öğdülmüş reminds him that "to call a person 'childless' is an insult" (KARABAŞ 1996, 69).

The inability to procreate is a serious source of family disputes in contemporary Turkish society, and children are still regarded as the primary source of affective ties and prosperity in the family. Parents, especially in rural regions, look upon their children for economic and emotional support in all stages in their life (KAĞITIÇIBAŞI 1981, 83). Even when economic ties are weak, affective ties are strong (KAĞITIÇıBAŞI 1996, 45-46). This family structure is also reflected in a number of proverbs in Turkish. One proverb says, "A man without children is like a tree with no fruit." Another proverb presents the interdependence between parents and children from the child's perspective: "The sun never rises on the forehead of an orphan."

The predominant assumption that the family essentially includes children is readily seen in openings in Turkish conversations between adults meeting for the first time. After preliminary formulaic questions on work, age, and marital status, the question that immediately follows the answer that a participant is married is whether he or she has children. This question is uttered so automatically, especially in television and radio talk shows, that when a negative answer is given a rather long pause ensues. This very frequently 
leads to a break in the smooth flow of a two-way conversation. The embarrassment that a negative answer causes to the participant who initially asked the question is clear by the difficulty that the person experiences in providing a follow-up response. This characteristic structure of openings in conversations is an indication of the deeply ingrained assumption that children form the defining feature of "family."

\section{Lamb Symbolism in "The Reed Door" and Turkish Culture}

The role of children in ancient texts and the above-mentioned structure in present-day conversational discourse sheds light on the function of the lambs/children in the tale and the way it symbolizes the possible plight for parents of losing or not having children. If it is assumed on the basis of the expressions used to address children in contemporary Turkish that the lamb represents children, the run uttered by the lamb in RD1, which implies strength and courage (lines d-ddddd, being able to hit with its horn and prod with its tail), is semantically coherent with the significance attached to children in Turkish culture for the well-being of the family. The lambs/children in "The Reed Door" function as protectors of the family similar to the manner Boğaç saves his father from kidnappers in Dede Korkut.

The lamb's supposed strength neatly parallels the contemporary perception of children as sources of well-being in the family. In this interpretation, it is significant that the wolf first addresses the door and not the husband and wife in the tale. Men who are physically strong are frequently referred to as being "like a door." The lexical item "door" appears with this figurative meaning in other expressions in Turkish. For example, a reliable and prestigious document that would entitle one to a number of social rights is called "a door." Given these associations and the custom referred to concerning the rise in status once one has children, the door in the tale and the lamb (or child) acquire identical roles as keepers of the family in the tale.

Indeed, the manner with which the runs of the wolf and the lamb in $\mathrm{RD} 1$ are narrated is meaningful in this respect. The narrator does not make it clear whether the wolf is made to go away because it hears a bold human (or animal) voice speaking or because it thinks that the response comes from the door. The extract below repeats the runs:

(ccc) "Reed door, I will break you;

(cccc) Husband and wife, I will eat you," it [the wolf] said.

(d) The lamb inside said:

(dd) "I'll hit with my horn,

(ddd) prod you with my tail.

(dddd) Don't come in, 
(ddddd) I'll eat you," it said,

(e) and the wolf got frightened,

(ee) and ran away.

The simile drawn between the concepts "door" and "man" is also closely related to the lamb's run and existing folklore elements. It is highly likely that the lamb in RD1 is not a female but a male. In manis in Turkish, female lambs are referred to with epithets such as "lamb whose horns have henna," while male lambs have black horns, a color signifying strength in Turkish culture (KARABAŞ 1977). In WALKER's (1988) variant, one of the kids acts fearlessly and uses a bold tone to hold off the bear. The female lamb/kid figures in published variants of AT 123 do not rely on their strength but on their wit to make the wolf go away (cf. BORATAV 1992a and SiLAY 1988).

That the lambs/children in "The Reed Door" rely on physical strength in protecting the household is congruous both with the fact that the tale was originally narrated by a woman from southeastern Turkey and with the role attached to sons in several regions in Anatolia. Women who give birth to sons acquire more prestige than women who bear daughters. Especially in the eastern parts of the country, sons are looked upon as a major source of strength and have a greater say in family affairs than daughters. Physical prowess is a crucial feature of males in epic narratives and folklore, too. This social patterning is observable in the Dede Korkut narrative, where Dirse Khan's son gains the title of khan after several accomplishments involving his brawn. "The Reed Door," with its stress on physical power, reflects a continuation of this tradition. ${ }^{8}$

The similarity between the predicament of the lamb in version $\mathrm{RD} 1$ of "The Reed Door" and that of Dirse Khan's son in Dede Korkut is worth noting. In the epic, the son is dangerously wounded by his own father, and in $\mathrm{RD} 1$ the lamb is at the mercy of the husband and wife. The fact that the lamb is only seemingly strong forms the turning point in the tale as the lamb is actually an easy prey both for the wolf and the parents. The motif of parental treachery and filial altruism in the tale accords with parent-child relations in Dede Korkut.

Parents protecting offspring is one predominant motif in published versions of AT 123 in Turkish, and it is implied in versions RD2 and RD3 of "The Reed Door" when the lambs/children become easy prey for the wolf while the sheep/human parents are away. In most variants of AT 123, the sheep/nanny goat saves the lives of the children (BORATAV 1992a, HELIMOĞLU YAVUZ 1997, and WALKER 1988). I would argue that "The Reed Door" shifts focus to show the predicament of the older generation if the young are not cared for. This is especially apparent in RD1. It underscores the belief that 
the well-being and prosperity of parents are dependent on their progeny's well-being. Indeed there are other folktales in Turkish originating from the same region as "The Reed Door," in which parents suffer tribulation on the grounds that they have caused the death of their children (cf. BORATAV 1992b). If the argument that the communicative function of the tale concerns the loss of children is correct, then the appearance of the bone motif can be seen to cohere with this function by symbolizing the "continuation of the species." The loss of offspring (or children) results in the loss of family. In this sense, the tale can be understood as one that explicitly marks the communicative value of the other variants of AT 123 in Turkish folklore, that is, the essential affective interdependency between parents and children in the family structure. ${ }^{9}$ It also encodes its own regional worldview regarding the importance of sons in the family.

\section{Bones in Turkish Discourse}

The bone motif in "The Reed Door" can be compared with its semantic value in contemporary Turkish discourse. A number of idioms with strong emotive connotations in Turkish reveal a close tie between the soul, one's inner feelings, and bones. For example, when talking about an undesirable turn of events in an act of social improvement that had formerly been initiated by a now deceased person, speakers may express their deep concern about the social issue by referring to the deceased as "his/her bones must be aching in his/her grave." Such expressions could be remnants of the belief that bones are the container of "the most important soul" (CHEVALIER and GHEERBRANT 1994, 109). Though its literal meaning is horrifying, the significance of bones is also present in another expression. One of the harshest forms of admonition that some parents use with their children is "I'll break your bones." EYUBOĞLU $(1998,162-63)$ in his discussion of the worth attached to bones remarks that the worst kind of swear words to be uttered to a person in Eastern Anatolia is one directed to the bones of a deceased parent.

While such patterns of lexical usage may exist in other cultures too, a formulaic expression regarding the education of children is more informative in the semantic connection it establishes between bones and survival. Until very recently, the expression was traditionally used in the initiation to formal education. Parents taking their child to school and handing over, so to speak, their child to the teacher would say, "His/Her (the child's) flesh is yours; the bones are ours." This formula has usually been interpreted as giving the teacher the right to beat the child (AKsoY 1991, 712). It is also a way of showing respect to the teacher, implying that the child is fully under the responsibility of the teacher. Whatever its function may be in social interaction, 
the expression clearly echoes the functioning of the bones in the tale. The bones or offspring are vital to the survival of the family.

\section{CONCLUSION}

"The Reed Door" can be read as a metaphor regarding the significance of children in the Turkish family structure. The performative role of the lambs/ children and the bone motif function as reflections of the social assumption that children are essential to the family structure. The function of the lambs/children in the tale closely resembles that of children in ancient Turkic narratives. Furthermore, within the context of Turkish folklore and contemporary Turkish discourse, the semantic value of the linguistic elements in the tale-_lamb," "door," and "bones"-form a coherent whole that represents children as the protectors of the Turkish family structure.

Though the tale diverges from other variants of AT 123 in Turkish folklore, its plot provides a comparative source for understanding the semantic significance of the tale type in Turkish culture. By unfolding a plot that pictures the destruction of the family if progeny are lost, the tale brings to the surface narration an ending that is only implicitly present in other variants of the tale. Indeed, this version of the tale reconstructs and thereby perpetuates the perception of children as defenders of the family. Indirectly, it provides for children a complimentary image of themselves. If this was not true, it would be difficult to account for why this tale with such a gruesome end was a popular bedtime story.

\section{NOTES}

1. The source of the oral rendering of the tale is a male teacher, aged 53 years, who had heard it from his mother, born in Kilis, a town in southeastern Turkey. The narrator remarked that the tale was a popular bedtime story for children in the family. The two other versions of the "The Reed Door" come from members of the man's extended family.

2. The translation of the story is kept as close as possible to the original syntax and semantics in order to reflect the expressive characteristics of the original language, following the examples of translations of runs in ZEYREK (1993).

3. In his classification of Turkish folktales, BORATAV (1992a, 270) notes comparable replacements of human figures by animal figures. DUNDEs $(1998,132)$ also observes that the same tale type may be rendered with either human or animal characters.

4. The mani in Turkish is a kind of oral folk poetry in the form of quatrains. It may or may not be sung to music.

5. The motif of protection of the family by offspring is present in an African folktale retold by Alexander MCCALL SMITH $(1993,9-13)$. In this story a boy who has been sent to the forest to pick fruit encounters a strange animal. The boy is able to prevent it from harming him by playing the drum. He recounts his encounter with this animal to his parents and aunt. The aunt does not believe him, but the father does. The following day the family goes to the forest. The animal first eats up the parents, then the aunt. By playing the drum fast, the boy 
makes the animal spit out the parents, and is then instructed by his father to rescue the aunt in the same way. This plot suggests that protection of family by a progeny is not a motif that is limited to "The Reed Door."

6. REICHL $(1992,104)$ records an explanation of the horsehead of the morin xuur (lit., "horse-fiddle") in Mongolian folktales in a manner similar to the European folktale of the singing bones (AT 780). BORATAV (1992a, 277) also notes a version of the singing bone motif in which the hard outer skin of a pumpkin that is usually used to make a stringed instrument replaces the bones in Type 780 . It may be concluded that bone motifs are not foreign to Mongolo-Turkic cultures.

7. The original of the two proverbs are

a. "Çocuksuz baba meyvasız ağaca benzer" (lit., "A father without children is like a tree with no fruit")

b. "Öksüzün anlina güneş doğmaz" (lit., "The sun never rises on the forehead of an orphan")

The first proverb is particularly instructive regarding some forms of compliments among men in Turkish conversations. Young men sometimes compliment men who act as competent guides to children and who get along well with them with remarks such as "You should have plenty of children" or "You should have a large family." Such compliments imply that the person giving the compliment regards the person he is complimenting as someone who is/would be a very good family man. In this way, such compliments and the proverb define an ideal adult male as one who has children. The second proverb means that an orphan never lives (i.e., experiences) a happy or prosperous day.

8. There is a formulaic expression in Turkish discourse that exhibits a similar pattern of socially expected altruistic behavior, even though it is uttered in a jocular manner more for the purpose of empathizing with someone's complaints about other people's behavior: "You say it, and I'll___, " filling in the blank with words such as "put him/her in his/her place," "beat him/her up."

9. The idea that the communicative intent of AT 123 primarily relates to family ties is supported by the fact that its variants in Turkish folklore are not connected to tales of "The Little Red Riding Hood" type (AT 333) in collections of folktales that have been examined for this study. "The Lamb with Henna" (GürGÖZE 1997) is one exception.

\section{APPENDIX}

\section{"Kamış Kapı"}

(a) Evvel zaman içinde, kalbur saman içinde, develer tellal iken, pireler berber iken, ben babamın beşiğini tıngır mıngır sallarken

(b) memleketin birinde minicik bir evde yaşayan bir karı koca bir de onların minicik bir kuzusu varmıs.

(c) Bu aile huzur içinde yaşarken bir gün kapının önüne bir kurt gelmiş

(cc) ve şöyle demiş:

(ccc) "Kamıskapı, kırarm seni,

(cccc) kar koca, yerim sizi” demiş

(d) İçerdeki kuzu: 
(dd) "Boynuzumla vururum,

(ddd) kuyruğumla dürterim.

(dddd) Girme içeri,

(ddddd) yerim seni," demiş.

(e) Kurt da korkmus,

(ee) kaçmış.

(c) Ertesi gün gene aynı olay yaşanmış.

(cc) Kurt geliyor:

(ccc) "Kamıs kapı, kırarm seni,

(cccc) kar koca, yerim sizi," diyor.

(d) İçerden gene bizim kuzu:

(dd) "Boynuzumla vururum,

(ddd) kuyruğumla dürterim.

(dddd) Girme içeri,

(ddddd) yerim seni," diyor.

(e) Kurt gene korkup kaçıyor.

(f) Karı koca ertesi gün karar veriyorlar:

(ff) "Bu kuzuyu keselim de

(fff) etini yiyelim," diyorlar

(ffff) ve kesiyorlar.

(ffff) Zavallıcık kuzu, etini yiyorlar.

(ffffff) Kemiklerini çöp tenekesine koyuyorlar.

(c) Ertesi gün kurt tekrar geliyor:

(cc) "Kamıs kapı, kırarm seni,

(ccc) kan koca yerim sizi," diyor.

(d) Bu sefer çöp tenekesindeki kuzunun kemikleri:

(dd) "Boynuzumla vururum,

(ddd) kuyruğumla dürterim.

(dddd) Girme içeri,

(ddddd) yerim seni," diyor.

(e) Kurt gene korkup kaçıyor.

(g) Ertesi gün çöpçü geliyor,

(gg) çöpleri alıp götürüyor.

(c) Kurt tekrar geliyor:

(cc) "Kamıs kapı, kırarm seni,

(ccc) kan koca, yerim sizi," diyor

(h) ve duruyor; bekliyor, bekliyor.

(hh) İçerden hiçbir ses gelmiyor.

(hhh) Kamıs kapıyı kırıyor,

(hhhh) içeri giriyor

(hhhhh) ve karı kocayı yiyor. 


\section{REFERENCES CITED}

AksoY, Ömer Asım

1991 Deyimler sözlüğü [Dictionary of idioms]. İstanbul: İnkılâp Kitabevi.

Ashliman, David L.

1987 A guide to folktales in the English language. New York: Greenwood Press.

Boratav, Pertev N.

1992a Az gittik uz gittik [Little we went, far we went]. İstanbul: Adam Yayıncılık. (First published 1962)

1992b Zaman zaman içinde [Time in time]. İstanbul: Adam Yayıncılık. (1958 reprint)

CHEVliER, Jean and Alain GHEERBRANT

1994 A dictionary of symbols. John Buchanan-Brown, trans. Oxford: Blackwell.

ÇORUHLU, Yasar

1999 Türk mitolojisinin $A B C$ 'si [Fundamentals of Turkish mythology]. İstanbul: Kabalc1 Yayınları.

DUNDEs, Alan

1989 Folklore matters. Knoxville: University of Tennessee Press.

1998 Motif indeks ve masal tip indeksi: Bir değerlendirme [Motif index and folktale typology: An evaluation]. Milli Folklor [National folklore] 39: 130-35.

EyuboĞLu, Ismet Zeki.

1998 Anadolu inançlar [Anatolian folklore]. İstanbul: Toplumsal Dönüşüm Yayınları.

GÜLICH, Elisabeth and Uta M. QUASTHOFF

1985 Narrative analysis. In Handbook of discourse analysis, vol.2: Dimensions of discourse, ed. Teun van Dijk, 169-97. London: Academic Press.

GÜRGÖZE, Mediha

1997 Anadolu masallarn [Anatolian Folktales]. İstanbul: Okyanus.

HelimoĞLu Yavuz, Muhsine

1997 Masalların eğitimsel işlevleri [The educational function of folktales]. Ankara: Ürün Yayınları.

KAĞITIÇıBAŞI, Çiğdem

1981 Value of children, women's role and fertility in Turkey. In Women in Turkish society, ed., Nermin Abadan-Unat, 74-95. Leiden: E. J. Brill.

1996 Cross-cultural psychology and development. In Asian contributions to cross-cultural psychology, eds. Janak Pandey, Durganand Sinha, and Dharm P. S. Bhawuk, 42-49. New Delhi: Sage Publications.

Karabaş, Seyfi

1977 Anlama yönelik çalışmalar ile dilsel budunbilim ürünlerinin sağlkılı derlemesi [Meaning-directed studies and the proper collecting of oral folklore products]. In Türkiyede toplumsal bilim arastırmalarında yaklaşımlar ve yöntemler [Approaches and methods in social sciences in Turkey], eds. Seyfi Karabaş and Yaşar Yeşilçay, 173-97. Ankara: Middle East Technical University,

1996 Dede Korkut'ta renkler [Color terminology in Dede Korkut]. İstanbul: Yapı Kredi Yayınları.

KunOS, Ignasc

1991 Türk masalları [Turkish folktales]. Trans. Gani Yener. İstanbul: Engin Yayıncılık. LABOV, William

1972 Language in the inner city: Studies in the black English vernacular. Philadelphia: University of Pennsylvania Press. 
MCCALl SMITH, Alexander

1993 Children of wax. Edinburgh: Clarendon Press. (First printed 1989.)

REICHL, Karl

1992 Turkic oral epic poetry: Traditions, forms, poetic structure. New York: Garland Publishing.

\section{Rigney, Anne}

1992 The point of stories: On narrative communication and its cognitive functions. Poetics Today 13: 263-83.

SILAY, Mehmet

1988 Hatay masallan [Folktales from Hatay]. İstanbul: Hatay Yayınları.

THOMPSON, Stith

1955 Motif-Index of folk literature. 6 vols. Rev. ed. Bloomington and Indianapolis: Indiana University Press.

WALKER, Barbara

1988 Who's there? And what do you want? A treasury of Turkish folktales for children. Hamden, Connecticut: Linnet Books.

ZeYrek, Deniz

1993 Runs in folktales and the dynamics of Turkish runs: A case study. Asian Folklore Studies 52: 161-75. 